\title{
Prevalence of Burkholderia glumae in rice crops in Ecuador ${ }^{1,2}$
}

\author{
Lenin Celiano Paz-Carrasco ${ }^{3 *}$, Luz Diana Intriago-Mendoza ${ }^{3}$, \\ Marcos Fernando Basso ${ }^{4}$ and Roberto E. Celi-Herán ${ }^{5}$
}

J. Agric. Univ. P.R. 102 (1-2):65-78 (2018)

\begin{abstract}
Burkholderia glumae is the agent responsible for bacterial panicle blight disease (BPBD) of rice that causes severe damage to this crop worldwide. During 2012 and 2013, symptoms of BPBD were observed in Palestina city, located in Guayas province, Ecuador. In 2014, the presence of B. glumae was confirmed at this location. In view of the socio-economic importance of rice in Ecuador, this research aimed to investigate the prevalence of $B$. glumae in other rice-producing regions. Eighteen bacterial isolates obtained from blighted kernels were characterized. Physiological, biochemical, serological, and molecular assays and the amplification of the 16S-23S rRNA ITS of the bacterial isolates collected confirmed the identity of the BPBDassociated bacterium. Pathogenicity assays verified the ability of these isolates to produce discoloration, spotting, and empty grains, symptoms associated with BPBD. Antibiotic assays showed that EC-EELS-01 isolate was sensitive to ciprofloxacin and tetracycline, and resistant to polymyxin. The dissemination and prevalence of $B$. glumae were confirmed in the riceproducing areas of El Oro, Cañar, Guayas, and Los Rios provinces. This research will serve to develop genetic studies to characterize the population in the B. glumae isolates in Ecuador.
\end{abstract}

Key words: antibiotic sensitivity; bacterial panicle blight; pathogenicity assays; serological and molecular diagnosis.

\section{RESUMEN}

\section{Prevalencia de Burkholderia glumae en cultivos de arroz en Ecuador}

Burkholderia glumae es el agente causal de la enfermedad del añublo bacterial de la panícula (bacterial panicle blight disease, BPBD) que

${ }^{1}$ Manuscript submitted to Editorial Board 21 August 2018.

${ }^{2}$ This research was supported by INIAP's Project "Cambio de la Matriz Productiva". Authors gratefully acknowledge Dr. Iris Perez-Almeida, Dr. Richard Hall, and Karla Zuniga-Gonzalez, BSc (Hons) for critically reviewing the manuscript. We also thank Mrs. Monica Puga-Santafe for her technical assistance in lab and greenhouse activities.

${ }^{3^{*}}$ National Institute of Agricultural Research (INIAP), Plant Pathology Department and Rice Breeding Program. Km 26 vía Duran-Tambo, Yaguachi, Guayas, Ecuador; Corresponding authors lenin.paz@iniap.gob.ec, roberto.celi@iniap.gob.ec, diana.intriago@iniap.gob.ec.

${ }^{4}$ National Center for Agroenergy Research (EMBRAPA Agroenergy), Plant Biotechnology Laboratory, Brasília, DF, 70770-917, Brazil; marcosbiotec@gmail.com.

${ }^{5}$ Rice Breeding Program. Km 26 vía Duran-Tambo, Yaguachi, Guayas, Ecuador. 
causa daños severos al cultivo de arroz mundialmente. Del 2012 al 2013, los síntomas del BPBD se observaron en el cantón de Palestina, de la provincia del Guayas, Ecuador. En el 2014, se confirmó la presencia de $B$. glumae en este cantón. En vista de la importancia socio económica del cultivo del arroz en Ecuador, el objetivo de esta investigación fue investigar la prevalencia de $B$. glumae en otras localidades productoras de arroz. Se caracterizaron dieciocho aislados de bacterias obtenidas de granos afectados. Ensayos fisiológicos, bioquímicos, serológicos y moleculares que incluyeron la amplificación de la región ITS 16S-23S del ARNr de los aislados confirmaron la identidad de B. glumae. Ensayos de patogenicidad realizados en panículas de la variedad de arroz INIAP 15 verificaron la habilidad de cuatro aislados (i.e., EC-EELS-01, -02, -03 y -07) para causar descoloración, manchado y granos vanos que corresponden a síntomas asociados a BPBD. Los ensayos con antibióticos mostraron que el aislado EC-EELS-01 era sensible a la ciprofloxacina y a la tetraciclina y resistente a la polimixina. La diseminación y prevalencia de $B$. glumae se corroboraron en las áreas productoras de arroz en las provincias de EI Oro, Cañar, Guayas y Los Ríos. Esta investigación proveerá una base para desarrollar un estudio genético y caracterizar la estructura poblacional de B. glumae en Ecuador.

Palabras clave: sensibilidad a antibióticos, añublo bacterial de la panícula del arroz, patogenicidad, diagnóstico serológico y molecular

\section{INTRODUCTION}

Bacterial panicle blight disease (BPBD), also called bacterial grain rot or panicle blight, is considered a major disease of rice (Oryza sativa L.), causing severe damage to this crop worldwide (Nandakumar et al., 2009; Lee et al., 2016a; Bigirimana et al., 2015; Mondal et al., 2015). Bacterial panicle blight disease was first reported in Japan, causing grain rotting and seedling blight on rice (Goto and Ohata, 1956). Since then, the disease has been reported in several countries of Africa, Asia, South and Central America; shifting from being considered a minor plant disease to a major problem due to environmental conditions (Cui et al., 2016b). The causal agent of this disease can be either a single Burkholderia species or a combination of several, which are mainly seed-transmitted. At present, there are no chemical options to control bacterial infected rice crops (Ham et al., 2011; Lee et al., 2016a).

Burkholderia glumae is the major causal agent of BPBD on rice, belonging to the Class II: Betaproteobacteria, Order Burkholderiales of the Family Burkholderiaceae (Kurita and Tabei, 1967). Rice is considered its main host plant (Lee et al., 2016a; Magbanua et al., 2014; Sharma et al., 2013). It can survive on rice leaves and sheaths, spreading upwards as the plant grows (Ham et al., 2011). Seedling rot induction, grain discoloration, grain rot and leaf-sheath browning, as well as flower sterility and decrease of grain weight are typical symptoms of the disease (Hikichi, 1993; Cottyn et al., 1996). Daytime temperatures 
$>32^{\circ} \mathrm{C}$, nighttime temperatures $>25^{\circ} \mathrm{C}$, and high humidity contribute to disease development (Cui et al., 2016). Apart from the detrimental effects on rice crops, this bacterium is also responsible for wilting of other crops, such as Capsicum annuum, Sesamum indicum, Solanum lycopersicum, S. melongena and Perilla frutescens var. japonica Hara (Jeong et al., 2003).

Burkholderia glumae is an aerobic motile, gram-negative bacterium that possesses two to four polar flagella, generally of $0.5-0.7 \mathrm{x}$ 1.5-2.5 $\mu \mathrm{m}$ in diameter. The production of toxoflavin and lipases, along with the polar flagella represent important virulence determinants (Jeong et al., 2003; Nandakumar et al., 2009; Lee et al., 2016b). On potato agar, the bacterium can produce a fluorescent pigment. Bacterial growth temperature ranged between 11 and $40^{\circ} \mathrm{C}$, having an optimal temperature between 30 and $35^{\circ} \mathrm{C}$. It is able to hydrolyze gelatin, while nitrate reduction, arginine dihydrolase, starch hydrolysis, and hydrogen sulfide production are negative (Palleroni, 2015; Urakami et al., 1994). Acids are produced from various sources, such as arabinose, glucose, fructose, galactose, mannose, xylose, glycerol, mannitol, and inositol, while no acid is produced from rhamnose, sucrose, maltose, lactose, raffinose, dextrin, starch, inulin or salicin (Palleroni, 2015). On YPDA medium, colonies produced a yellow pigment soluble in chloroform (Ura et al., 2006). Burkholderia glumae usually grows at $40^{\circ} \mathrm{C}$ on a culture medium containing $3 \% \mathrm{NaCl}$ and utilizes several compounds as carbon source [for a complete list, please, review Palleroni (2015)]. Colonies do not produce fluorescent pigment on King B medium. Nevertheless, an intense yellow pigment is produced, which diffuses through the media due to the production of toxoflavin (Nandakumar et al., 2009; Lee et al., 2016b). Rice spikelets infected by this phytotoxin display symptoms of brown stripes on both the palea and lemma, which are modified stems that protect flower organs, inhibiting the growth of whole rice plants (Iiyama et al., 1995).

In 2013, typical symptoms of stained, discolored and abortive or unfilled grains were observed in rice panicles grown at Palestina city of Guayas province of Ecuador. Riera et al. (2014) reported $B$. glumae as the disease causal agent resulting in yield and grain quality losses. Burkholderia glumae has also been reported in other countries, such as Colombia (Zeigler and Alvarez, 1989), Panama (Nandakumar and Rush, 2007), USA (Nandakumar et al., 2009), Dominican Republic, Venezuela, Brazil, Nicaragua and Costa Rica (Cui et al., 2016). Other pathogens cause symptoms similar to those of $B$. glumae. Pseudomonas fuscovaginae, for example, also causes staining of grains and sheaths, and even destruction of the flower reproductive organs (Zeigler and Alvarez, 1987a). Furthermore, P. fuscovaginae, 
like $B$. glumae, also causes sheath rot and grain discoloration, which can make it difficult to distinguish symptoms and damages caused by these two species (Cottyn et al., 1996). The primary goal of this research was to study the prevalence of $B$. glumae in rice fields in Ecuador and to characterize 18 isolates causing BPBD.

\section{MATERIALS AND METHODS}

\section{Isolation of bacterial isolates from symptomatic rice seeds}

From 2014 to 2015 rice panicles presenting discolored and unfilled grain symptoms (Figures 1A to C) were harvested at four localities: Cañar, El Oro, Guayas and Los Ríos, Ecuador (Table 1). From each plant sample, 10 symptomatic rice grains were selected, placed in $1.5 \mathrm{~mL}$ microtubes containing $1 \mathrm{~mL}$ sterile water and incubated for $4 \mathrm{~h}$ at $37^{\circ} \mathrm{C}$. After incubation, an aliquot of these samples was streaked on King B medium (King et al., 1954) and incubated at $37^{\circ} \mathrm{C}$. Bacterial colonies showing circular shape, cream color, smooth and convex elevation, with translucent and complete borders were selected and isolated in pure culture. Gram-negative test was performed by a solubility assay in $3 \% \mathrm{KOH}$ (Suslow et al., 1982). Selected colonies were grown on bacteria screening medium 523 (Kado and Heskett, 1970).

\section{Physiological, biochemical and nutritional characteristics}

Bacterial cultures $(48 \mathrm{~h}$ ) were used for the following tests: (i) physiological assays of fluorescence under UV light, diffusible pigment and toxoflavin production on yeast peptone dextrose agar (YPDA) and King B media; (ii) growth at $40^{\circ} \mathrm{C}$ on nutrient-broth yeast medium (NBY) (Schaad et al., 2001); (iii) determination of colony color on yeast dextrose calcium carbonate (YDC) medium (Schaad et al., 2001); (iv) growth on $\mathrm{pH} 4.0,8.0$, or 9.0 in LB liquid medium (Bertani, 1951); (v) growth at different $\mathrm{NaCl}$ concentrations (NBY medium plus 1.5, 2.0, 2.5 or $3.0 \% \mathrm{NaCl}$ ); (vi) aerobic growth; (vii) catalase assays with $3 \%$ hydrogen peroxide; (viii) biochemical assays to establish gelatin hydrolysis (basal medium containing nutrient agar $23 \mathrm{~g} / \mathrm{L}$ and microbiological gelatin $4 \mathrm{~g} / \mathrm{L}$ ) using Frazier's revealers ( $\mathrm{HCl} 200 \mathrm{~mL} / \mathrm{L} ; \mathrm{HgCl}_{2} 150 \mathrm{~g} / \mathrm{L}$ ); (ix); utilization of carbon sources: $1 \%$ of D-xylose, D-trehalose, and Dsorbitol in phenol red basal medium (Schaad et al., 2001); (x) determination of starch hydrolysis activity in a medium containing nutrient agar, potato soluble starch, and $\mathrm{pH} 7.0$; and (xi) pectinolytic activity on potato tuber slices. 

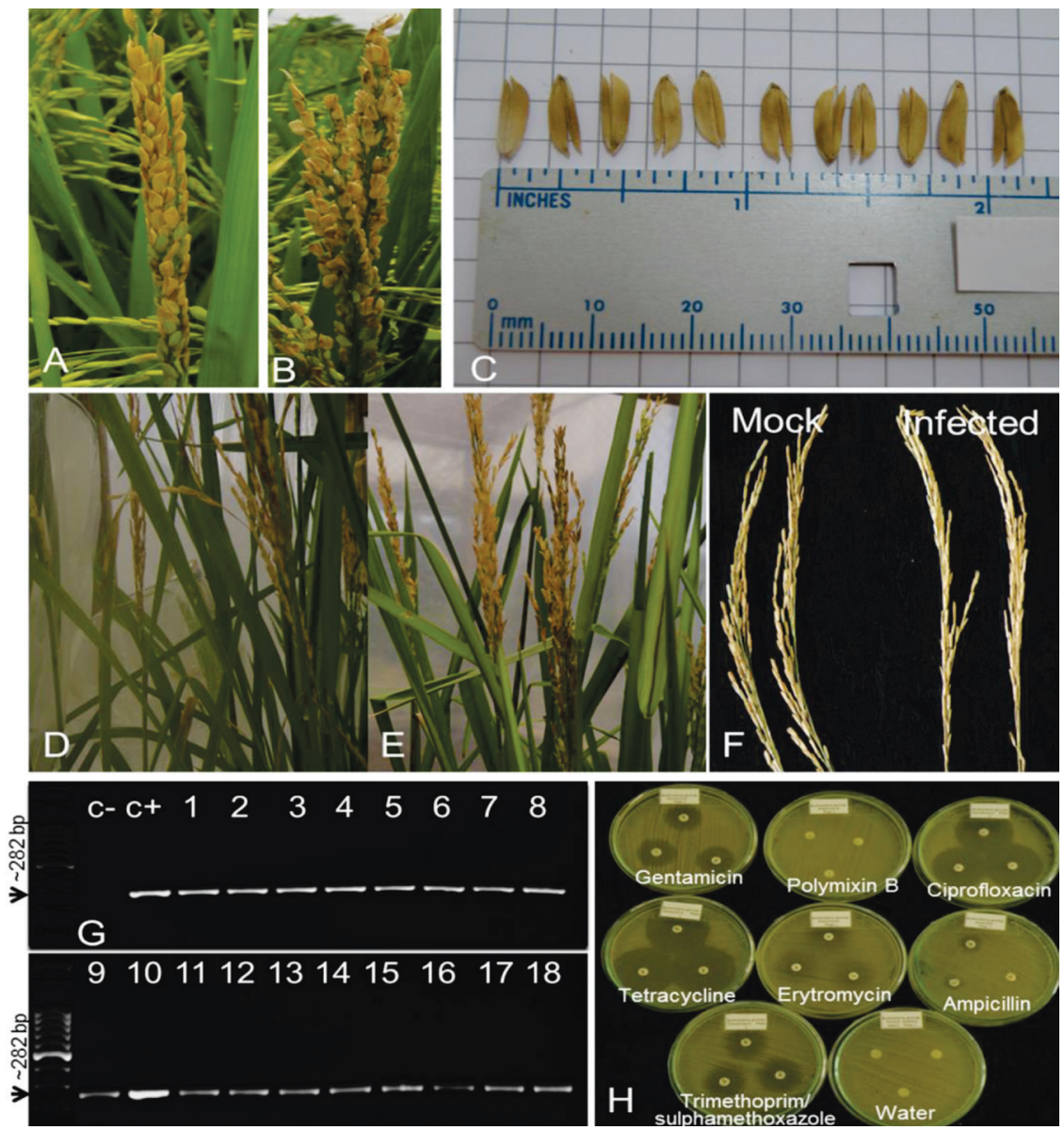

Figure 1. Bacterial Panicle Blight Disease (BPBD) symptoms (A-C) on rice panicles sampled from Ecuadorean rice plantations. A. Rice panicles carrying unfilled and spotted grains; B. Discolored and stained panicles; C. Unfilled, spotted and discolored rice glumae); D to F. Pathogenicity assays performed by spraying with Burkholderia glumae EC-EELS-01 isolate on rice variety INIAP 15; G. PCR assay showing specific amplification of 16-23S rRNA ITS region of $B$. glumae isolates $(\sim 282 \mathrm{bp})$. C- = Healthy rice (negative control), $\mathrm{C}_{+}=B$. glumae-infected rice (positive control), 1 to $18=B$. glumae isolates; H. Antibiotic sensitivity test using the EC-EELS-01 isolate with seven different antibiotics and a sterile water control.

\section{Serological and molecular analysis}

Indirect-ELISA (enzyme-linked immunosorbent assay) using a specific antibody against $B$. glumae (Agdia, Inc.) and PCR assays using specific primers were performed. A single colony was grown in Luria-Bertani (LB) liquid medium for $24 \mathrm{~h}$ at $37^{\circ} \mathrm{C}$ to isolate total 
TABLE 1.-Burkholderia glumae isolates collected from different rice producing locations in Ecuador.

\begin{tabular}{|c|c|c|c|}
\hline Isolate codes* & \multirow{2}{*}{$\begin{array}{l}\text { Locality } \\
\text { Montalvo }^{\mathrm{a}}, \text { Los Ríos }^{\mathrm{b}}\end{array}$} & \multicolumn{2}{|c|}{ Coordinates } \\
\hline 1 EC-EELS-01 & & S 0151’37."” & W 79²0’28.5” \\
\hline 2 EC-EELS-02 & El Triunfo, Guayas & $\mathrm{S} 02^{\circ} 18^{\prime} 38^{\prime \prime}$ & W $79^{\circ} 19^{\prime} 04.4^{\prime \prime}$ \\
\hline 3 EC-EELS-03 & El Triunfo, Guayas & S $02^{\circ} 18^{\prime} 38^{\prime \prime}$ & W $79^{\circ} 19^{\prime} 04.4^{\prime \prime}$ \\
\hline 4 EC-EELS-04 & Jujan, Guayas & S $01^{\circ} 56^{\prime} 45^{\prime \prime}$ & W $79^{\circ} 32^{\prime} 41.7 ”$ \\
\hline 5 EC-EELS-05 & El Triunfo, Guayas & S $02^{\circ} 24^{\prime} 19.5^{\prime \prime}$ & W 79³2’38.9” \\
\hline 6 EC-EELS-06 & Palestina, Guayas & S $01^{\circ} 32 ’ 51^{\prime \prime}$ & W 7957’23.9” \\
\hline 7 EC-EELS-07 & Arenillas, El Oro & S $03^{\circ} 29^{\prime} 49.8^{\prime \prime}$ & $\mathrm{W} 80^{\circ} 05^{\prime} 08.9^{\prime \prime}$ \\
\hline 8 EC-EELS-08 & Naranjal, Guayas & S $02^{\circ} 30^{\prime} 36.2^{\prime \prime}$ & W $79^{\circ} 36^{\prime} 12.8^{\prime \prime}$ \\
\hline 9 EC-EELS-09 & Yaguachi, Guayas & S $02^{\circ} 15^{\prime} 33.6^{\prime \prime}$ & W $79^{\circ} 38^{\prime} 37.6^{\prime \prime}$ \\
\hline 10 EC-EELS-10 & La Troncal, Cañar & $\mathrm{S} 02^{\circ} 23^{\prime} 51.8^{\prime \prime}$ & W $79^{\circ} 21^{\prime} 59.9^{\prime \prime}$ \\
\hline 11 EC-EELS-11 & Colimes, Guayas & S 01³2’45” & W $79^{\circ} 58^{\prime} 47^{\prime \prime}$ \\
\hline 12 EC-EELS-12 & Nobol, Guayas & S $01^{\circ} 55^{\prime} 34.3^{\prime \prime}$ & $\mathrm{W} 80^{\circ} 02^{\prime} 50.8^{\prime \prime}$ \\
\hline 13 EC-EELS-13 & Nobol, Guayas & $-^{\mathrm{c}}$ & - \\
\hline 14 EC-EELS-14 & Nobol, Guayas & - & - \\
\hline 15 EC-EELS-15 & Nobol, Guayas & - & - \\
\hline 16 EC-EELS-16 & Nobol, Guayas & - & - \\
\hline 17 EC-EELS-17 & Nobol, Guayas & - & - \\
\hline 18 EC-EELS-18 & Nobol, Guayas & - & - \\
\hline
\end{tabular}

${ }^{\mathrm{a}}$ County; ${ }^{\mathrm{b}}$ Province, and ${ }^{\mathrm{c}}$ same location coordinates as EC-EELS-12.

*Isolates were deposited in the Collection of Microorganisms Bank of INIAP, Ecuador.

DNA using Wizard® Genomic DNA Purification Kit ${ }^{6}$ (Promega). PCR analysis was carried out in an Agilent Technologies Sure Cycler 8800 thermal cycler. Amplification of the 16-23S rRNA ITS region of the $B$. glumae isolates was performed using specific primers to the Burkholderia species (forward) 5'-ACG TTC AGG GAT RCT GAG CAG-3' and (reverse) 5'-AGT CTG TCT CGC TCT CCC GA-3' (Sayler et al., 2006).

The PCR mix was composed of 1X GoTaq Flexi Buffer, $1.5 \mathrm{mM}$ $\mathrm{MgCl}_{2}, 0.2 \mu \mathrm{M}$ of dNTPs (Promega), $0.16 \mu \mathrm{M}$ of each primer (forward and reverse), 0.5 U GoTaq ${ }^{\circledR}$ Flexi DNA Polymerase (Promega), and $10 \mathrm{ng}$ of template genomic DNA. PCR products were separated by 1.2\% agarose gel electrophoresis (Promega) and immersed in Diamond $^{\mathrm{TM}}$ Nucleic Acid Dye intercalating solution (Promega). One Kb Plus DNA Ladder (Invitrogen) was used to estimate the length of PCR products.

\footnotetext{
${ }^{6}$ Manufacturer was mentioned to provide specific information and does not constitute a warranty by the University of Puerto Rico, nor is this mention a statement of preference over other companies.
} 


\section{Pathogenicity assays}

Four bacterial isolates (i.e., EC-EELS-01, -02, -03, and -07) were randomly selected to carry out pathogenicity assays using rice variety INIAP 15 and to confirm Koch's postulates. A single colony was used to obtain bacterial growth onto 523 solid media, resulting colonies were re-suspended and homogenized in sterile $0.85 \% \mathrm{NaCl}$ solution, and the $\mathrm{OD}_{600}$ was adjusted to 0.2 . Inoculations were performed on panicles in the anthesis stage using a manual sprayer, and the inoculated plants were immediately placed in a humid chamber at $42.8^{\circ} \mathrm{C}$ with $72.6 \%$ relative humidity. Control plants were mock inoculated with sterile water. After three days, typical symptoms were recorded and percentage of unfilled grains was assessed. Successful infection by B. glumae isolates was confirmed by PCR (as described previously) from inoculated panicle grains.

\section{Antibiotic susceptibility assays}

A randomly chosen isolate (EC-EELS-01) was tested using the disk antibiotic susceptibility test of Bauer-Kirby-Sherris-Truck (Bauer et al., 1966) with supplies from Bioanalyse ${ }^{\circledR}$ (ampicillin $10 \mathrm{mcg}$, ciprofloxacin $5 \mathrm{mcg}$, erythromycin $15 \mathrm{mcg}$, gentamicin $10 \mathrm{mcg}$, polymyxin B $300 \mathrm{U}$, tetracycline $30 \mathrm{mcg}$ and trimethoprim/sulphamethoxazole 1.25/23.75 mcg) (Bauer et al., 1966; Blazevic et al., 1972). Three disks of each antibiotic were placed in three individual Petri dishes containing Müller-Hinton agar and the inhibition halo diameters were measured.

Statistical analysis was performed using a completely randomized design and mean data were analyzed using Tukey test ( $\mathrm{p}$-value $>0.05$ ) by InfoStat software (Di Rienzo et al., 2016).

\section{RESULTS}

Isolation of the bacterial isolates and physiological, biochemical, nutritional characterization

Eighteen bacterial isolates were obtained from four localities sampled: El Oro, Cañar, Guayas and Los Ríos, Ecuador (Table 1). Colonies were cream in color, convex with a smooth surface and translucent border. All were considered Gram-negative bacteria (Table 2).

Colonies did not show enzymatic hydrolysis of fluorescein diacetate on King B medium. However, they displayed a diffusible yellowish and greenish color, which is typical of the toxoflavin toxin, confirmed by strong production of this pigment on YPDA medium. In addition, all isolates grown on NBY medium at $40^{\circ} \mathrm{C}$ and on YDC medium were light cream in color (Table 2). 


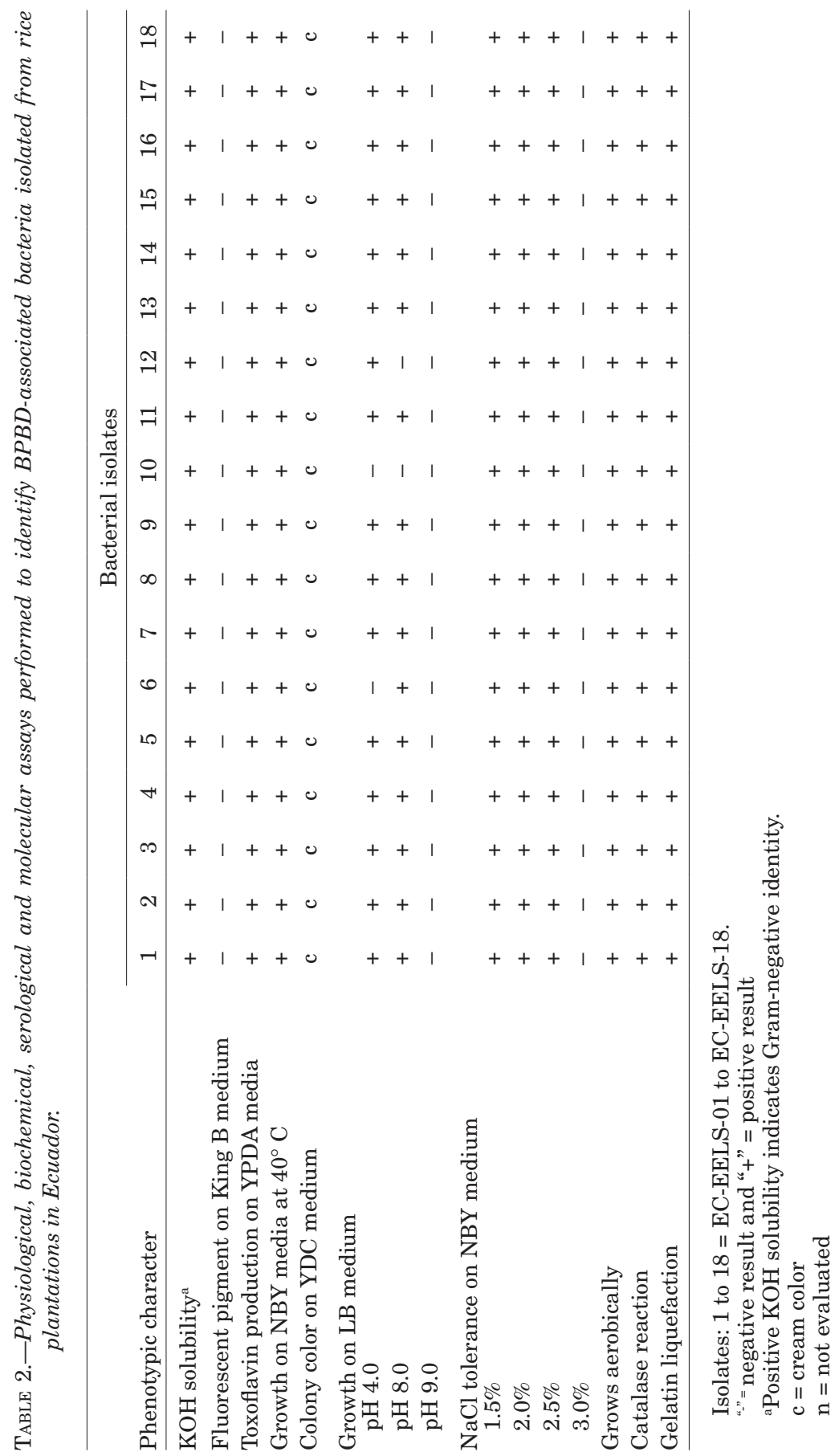


J. Agric. Univ. P.R. vol. 102, No. 1-2, 2018

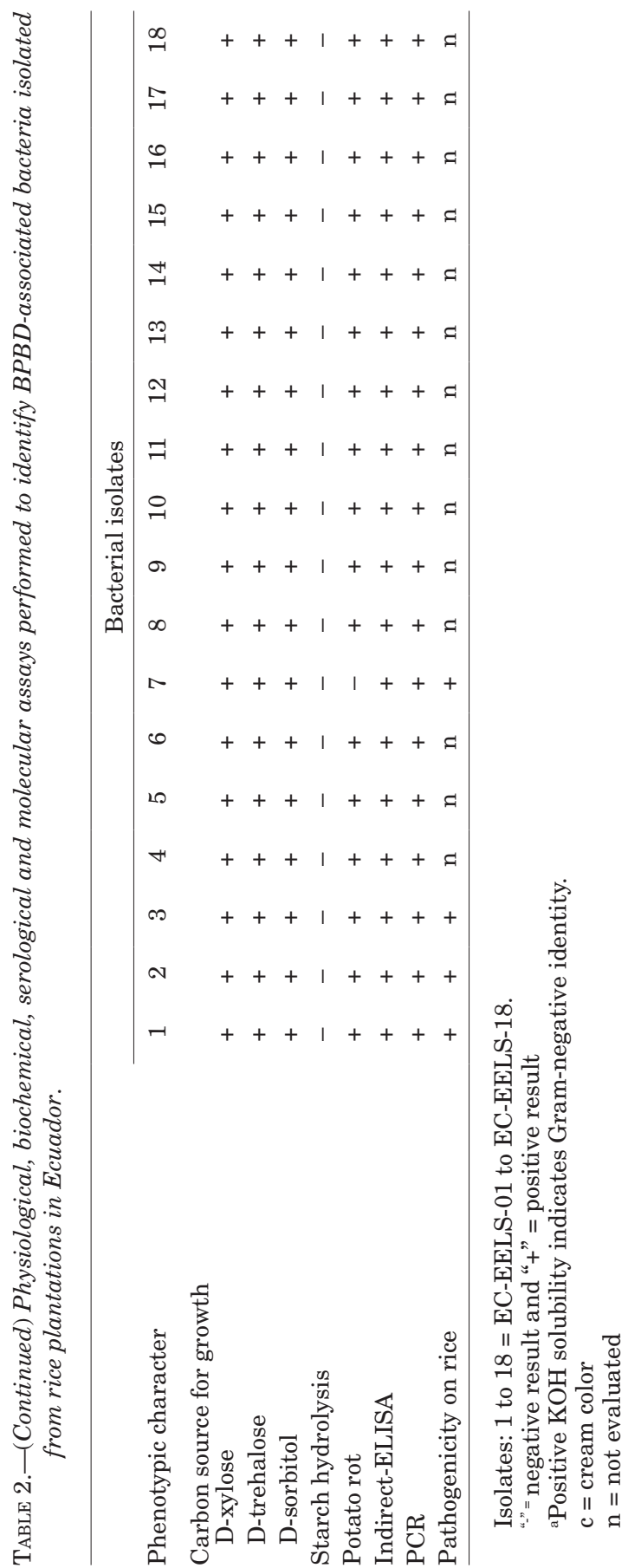


Non-bacterial growth was observed of isolates EC-EELS-06 and EC-EELS-10 in LB medium at pH 4.0, and isolates EC-EELS-10 and EC-EELS-12 at $\mathrm{pH}$ 8.0, while at $\mathrm{pH} 9.0$ none of the 18 isolates grew. Positive aerobic growth, catalase reaction, gelatin liquefaction, and ability to metabolize D-xylose, D-trehalose, and D-sorbitol as carbon sources were confirmed for all isolates (Table 2). All isolates were negative to starch hydrolysis with the exception of isolate EC-EELS-07 that did not display pectinolytic activity on potato slices (Table 2).

Serological and molecular detection

ELISA and PCR results confirmed the identity of B. glumae (Table 2 ). The PCR results for the 18 isolates using specifically designed primers (Sayler et al., 2006) for B. glumae showed an amplicon of expected size ( 282 bp) (Figure 1G).

\section{Pathogenicity assays}

Four isolates of $B$. glumae (i.e., EC-EELS-01, -02, -03, and -07) were inoculated on rice panicles of variety INIAP 15 causing $82.22,93.46$, 68.73 , and $80.74 \%$ vanishing of panicles, respectively (Figure $1 \mathrm{~F}$ ). Filled grain panicles only represented 12.33, 4.31, 26.06, and 14.0\% respectively. Remaining percentages corresponded to partly filled panicles $(5.45,2.23,5.21$ and 5.26\%). Externally the lemma and palea showed clear coffee color stain. Controls inoculated with sterile water did not display symptoms.

\section{Antibiotic susceptibility assays}

Assays of sensitivity to antibiotics showed that EC-EELS-01 isolate is sensitive to ciprofloxacin and tetracycline causing inhibition halos of 37.7 and $40.5 \mathrm{~mm}$, respectively. Furthermore, B. glumae isolate showed resistance to polymyxin B and a certain tolerance for ampicillin $(9.0 \mathrm{~mm})$, erythromycin $(12.8 \mathrm{~mm})$, trimethoprim $(22.4 \mathrm{~mm})$, and gentamicin $(23.1 \mathrm{~mm})$ (Figure $1 \mathrm{H})$.

\section{DISCUSSION}

Our results from physiological, biochemical, serological, and molecular assays showed that all 18 isolates had typical characteristics of $B$. glumae in agreement with reports by Palleroni (2015) and Schaad et al. (2001). The results confirmed the spread and prevalence of $B$. glumae, which has caused severe damage in the main rice producing areas of the provinces of El Oro, Cañar, Guayas and Los Ríos, Ecuador. Burkholderia glumae was first reported in Japan (Goto and Ohata, 1956) and subsequently detected in several other countries. In 2013 it 
was observed in the rice plantations of Palestina city, Guayas province, Ecuador (Riera et al., 2014). Since then, symptoms of BPBD on Ecuadorean rice plantations have been widespread and, most of the time, were associated with $P$. fuscovaginae (INIAP, 1987). In this research, we characterized $18 \mathrm{~B}$. glumae isolates harvested in associated with BPBD.

Bacterial isolates growth at the different $\mathrm{pH}$ showed lack of, or poor growth at extreme $\mathrm{pH}$ conditions, which corresponds to established parameters of B. glumae identification (Urakami et al., 1994; Palleroni, 2015). All isolates on NBY medium supplemented with 1.5, 2.0 or $2.5 \%$ $\mathrm{NaCl}$ developed, while no growth was observed at $3 \%$, showing lower tolerance to $\mathrm{NaCl}$ compared with isolates profiled in other studies that showed tolerance at $3 \% \mathrm{NaCl}$ (Zhou, 2014).

Pathogenicity assays, using four isolates randomly selected (i.e., EC-EELS-01, -02, -03, and -07), confirmed their ability to cause typical symptoms such as discoloration, stained, and unfilled grains in rice panicles (up to $81.19 \%$ ) of the rice variety INIAP 15 (Figure 1D to F). These results are consistent with grain damage (93.8\%) observed in the rice variety XXI (Fory et al., 2014). Mean temperature at Ecuadorian areas, where samples were collected, was $27.0^{\circ} \mathrm{C}$ (INAMHI, 2016). Under elevated temperature and humidity conditions, B. glumae causes gynoecium wilt and deformation, along with abortion of pollen grains because of colonization of the palea and lemma interior causing sterility ( $\mathrm{Li}$ et al., 2017). Toxoflavin production causes grain rotting and discolored panicles (Ilyama et al., 1995; Jeong et al., 2003; Luo et al., 2007; Mondal et al., 2015; Lee et al., 2016b). In our analysis, toxoflavin production by $B$. glumae was indicated by the production of a yellow pigment on a King's B agar plate.

In agreement with Bauer et al. (1966), B. glumae showed sensibility to tetracycline (that blocks binding of aminoacyl-tRNA to A site on the ribosome) and ciprofloxacin (a potent inhibitor of DNA gyrase). Oxytetracycline has the ability to inhibit bacterial growth without killing it and has been used to treat broccoli and cabbage infested with Xanthomonas campestris reducing infection to less than 1\% (Dekker, 1963). Similarly, treatment of rice seeds with oxolinic acid sprayed before and after panicle production has proved to be efficient in BPBD management (Hikichi, 1993). Nonetheless, some strains of B. glumae have been identified as being naturally resistant to oxolinic acid due to a gyrA mutation in the DNA gyrase (Naughton et al., 2016). However, Cui et al. (2014) demonstrated that metallic copper has an antibacterial effect against $B$. glumae by causing a buildup of copper in the bacterial cell, losing cell membrane integrity by directly affecting proteins and lipids, in addition to DNA degradation. Burkholderia glumae 
strain PG1 has specialized genes that encode degradation systems for toxic substances like atrazine, nitrotoluene, and nicotinate; as well as an efflux system for pumping out a broad range of antibiotics (Lee et al., 2016b). Therefore, it is necessary to explore genetic rice materials that show resistance to BPBD and investigate chemical molecules that can act as bactericides in disease management.

In summary, we identified 18 bacterial isolates of $B$. glumae, a pathogen associated with typical symptoms of BPBD. The bacterium is widespread in rice-producing areas in Ecuador. Symptoms observed in the field confirmed that B. glumae is one of the causal agents of vanishing panicles and decreased in rice yields. Currently, it is considered the second most important phytobacterium infecting rice in the country, following $P$. fuscovaginae.

Therefore, there is a compelling need to evaluate sources of rice germplasm resistance and use of pathogen-free seed. Thus, studies of genetic variability among $B$. glumae isolates are extremely important to determine the existence of population subdivision. Currently, our research team is sampling other rice regions aiming to develop a broad genetic study to establish population structure of $B$. glumae isolates in Ecuador.

\section{LITERATURE CITED}

Bauer, A. W., W. M.M. Kirby, J. C. Sherris, and M. Turck, 1966. Antibiotic susceptibility testing by a standardized single method. Diagnostic Microbiology and Epidemiology. Reprinted from Technical Bulletin of the Registry of Medical Technologists 36(3): 41-44.

Bertani, G., 1951. Studies on lysogenesis. The mode of phage liberation by lysogenic Escherichia coli. Journal of Bacteriology 62: 293-300.

Bigirimana, V. P., G. K. H. Hua, O. I. Nyamangyoku and M. Höfte, 2015. Rice sheath rot: An emerging ubiquitous destructive disease complex. Frontiers in Plant Science 6: 1066.

Blazevic, D. J., M. H. Koepcke and J. M. Matsen, 1972. Quality control testing with disk antibiotic susceptibility test of Bauer-Kirbi-Sherris-Turck. American Journal of Clinical Pathology 57(5): 592-597.

Cottyn, B., M. T. Cerez, M. F. Van Outryve, J. Barroga, J. Swings and T. W. Mew, 1996. Bacterial diseases of rice. I. Pathogenic bacteria associated with sheath rot complex and grain discoloration of rice in the Philippines. Plant Disease 80(4): 429-437.

Cui, Z-q., M. Ibrahim, C. Yang, C. L. Yang, Y. Fang, H. Annam, B. Li, Y. L. Wang, G. L. Xie and G. C. Sun, 2014. Susceptibility of opportunistic Burkholderia glumae to copper surfaces following wet or dry surface contact. Molecules 19: 9975-9985.

Cui, Z-q., B. Zhu, G-l. Xie, B. Li and S-w. Huang, 2016. Research status and prospect of Burkholderia glumae, the pathogen causing bacterial panicle blight. Rice Science 23(3): 111-118.

Dekker, J., 1963. Antibiotics in the control of plant diseases. Annual Review Microbiology 17: 243-262.

Di Rienzo, J. A., F. Casanoves, M. G. Balzarini, L. Gonzalez, M. Tablada and C. W. Robledo, 2016. Infostat version 2016. Grupo InfoStat, FCA, Universidad Nacional de Cordoba, Argentina. URL http://www.infostat.com.ar. 
Fory, P. A., L. Triplett, C. Ballen, J. F. Abello, J. Duitama, M. G. Aricapa, G. A. Prado, F. Correa, J. Hamilton, J. E. Leach, J. Tohme and G. M. Mosquera, 2014. Comparative analysis of two emerging rice seed bacterial pathogens. Phytopathology 104(5): 436-444.

Goto, K. and K. Ohata, 1956. New bacterial diseases of rice (bacterial brown stripe and bacterial grain rot) (Abstract in Japanese). Annals of the Phytopathological Society of Japan 21: 46.

Ham, J. H., R. A. Melanson and M. C. Rush, 2011. Burkholderia glumae: next major pathogen of rice? Molecular Plant Pathology 12(4): 329-339.

Hikichi, J., 1993. Relationship between population dynamics of Pseudomonas glumae on rice plants and disease severity of bacterial grain rot of rice. Journal of Pesticide Science 18(4): 319-324.

Iiyama, K., N. Furuya, Y. Takanami and N. Matsuyama, 1995. A role of phytotoxin in virulence of Pseudomonas glumae Kurita et Tabei. Annals of the Phytopathological Society of Japan 61(5): 470-476.

INAMHI, 2016. Boletín Climatológico Anual 2015, Instituto Nacional de Meteorología e Hidrología, Quito, Ecuador.

INIAP, Instituto Nacional de Investigaciones Agropecuarias, Estación Experimental Boliche. 1987. Manchado del grano. Informe Técnico Anual, pp. 8-14

Jeong, Y., J. Kim, S. Kim, Y. Kang, T. Nagamatsu and I. Hwang, 2003. Toxoflavin produced by Burkholderia glumae causing rice grain rot is responsible for inducing bacterial wilt in many field crops. Plant Disease 87(8): 890-895.

Kado, C. I. and M. G. Heskett, 1970. Selective media for isolation of Agrobacterium, Corynebacterium, Erwinia, Pseudomonas and Xanthomonas. Phytopathology 60: 969-976.

King, E. O., M. K. Ward and D. E. Raney, 1954. Two simple media for the demonstration of pyocyanin and fluorescein. Journal of Laboratory and Clinical Medicine 44: 301-307.

Lee, H.-H., J. Park, J. Kim, I. Park and Y.-S. Seo, 2016a. Understanding the direction of evolution in Burkholderia glumae through comparative genomics. Current Genetics 62(1): 115-123.

Lee, J., J. Park, S. Kim, I. Park and Y-S. Seo, (2016b). Differential regulation of toxoflavin production and its role in the enhanced virulence of Burkholderia gladioli. Molecular Plant Pathology 17(1): 65-76.

Li, L., L. Wang, L. Meng, Y. Xuan, S. Wen and Q. Qin, 2017. Infection process of Burkholderia glumae in rice spikelets. Journal of Phytopathology 165: 123-130

Luo, J., G. Xie and X. Lihui, 2007. First report of Burkholderia glumae isolated from symptomless rice seeds in China. Plant Disease 91(10): 1363.

Magbanua, Z. V., M. Arick, T. Buza, C-Y. Hsu, K-C. Showmaker, P. Chouvarine, P. Deng, D. G. Peterson and S. Lu, 2014. Transcriptomic dissection of the rice-Burkholderia glumae interaction. BMC Genomics 15: 755.

Mondal, K. K., C. Mani and G. Verma, 2015. Emergence of bacterial panicle blight caused by Burkholderia glumae in North India. Plant Disease 99(9): 1268.

Nandakumar, R. and M. C. Rush, 2007. Association of Burkholderia glumae and Burkholderia gladioli with panicle blight symptoms on rice in Panama. Plant Disease 91(6): 767.

Nandakumar, R., A. K. M. Shahjahan, X. L. Yuan, E. R. Dickstein, D. E. Groth, C. A. Clark, R. D. Cartwright and M. C. Rush, 2009. Burkholderia glumae and B. gladioli cause bacterial panicle blight in rice in the southern United States. Plant Disease 93(9): 896-905.

Naughton, L. M., S. An, I. Hwang, S. Chou, Y-Q. He, J-L. Tang, R. P. Ryan and M. Dow, 2016. Functional and genomic insights into the pathogenesis of Burkholderia species to rice. Environmental Microbiology 18(3): 780-790.

Palleroni, N. J., 2015. Burkholderia. Bergey's Manual of Systematics of Archaea and Bacteria. John Wiley \& Sons, Inc. p. 1-50.

Riera, C. A., J. D. Vargas, C. R. Cedeño, P. M. Quirola, M. Escobar, J. M. Cevallos, M. F. Ratti and E. Peralta, 2014. First report of Burkholderia glumae causing bacterial panicle blight on rice in Ecuador. Plant Disease 98(7): 988. 
Sayler, R. J., R. D. Cartwright and Y. Yang, 2006. Genetic characterization and RealTime PCR detection of Burkholderia glumae, a newly emerging bacterial pathogen of rice in the United States. Plant Disease 90(5): 603-610.

Schaad, N. W., J. B. Jones and W. Chun (eds.), 2001. Laboratory guide for identification of plant pathogenic bacteria. 3rd Ed. APS Press. The American Phytopathological Society.

Sharma, S., S. Sharma, A. Hirabuchi, K. Yoshida, K. Fujisaki, K. Ito, A. Uemura, R. Terauchi, S. Kamoun, K. H. Sohn, J. D. G. Jones and H. Saitoh, 2013. Deployment of the Burkholderia glumae type III secretion system as an efficient tool for translocating pathogen effectors to monocot cells. The Plant Journal 74(4): 701-712.

Suslow, T. V., M. N. Schroth and M. Isaka, 1982. Application of a rapid method for Gramn differentiation of plant pathogenic and saprophytic bacteria without staining. Phytopathology 72(7): 917-918

Ura, H., N. Furuya, K. Iiyama, M. Hidaka, K. Tsuchiya and N. Matsuyama, 2006. Burkholderia gladioli associated with symptoms of bacterial grain rot and leaf-sheath browning of rice plants. Journal General Plant Pathology 72: 98-103.

Urakami, T., C. Ito-Yoshida, H. Araki, T. Kijima, K-I. Suzuki and K. Komagata, 1994. Transfer of Pseudomonas plantarii and Pseudomonas glumae to Burkholderia as Burkholderia spp. and description of Burkholderia vandii sp. nov. International Journal of Systematic Bacteriology 44(2): 235-245.

Zeigler, R. S. and E. Alvarez, 1987. Bacterial sheath brown rot of rice caused by Pseudomonas fuscovaginae in Latin America. Plant Disease 71(7): 592-597.

Zeigler, R. S. and E. Alvarez, 1989. Grain discoloration of rice caused by Pseudomonas glumae in Latin America. Plant Disease 37(4): 368.

Zhou, X. G., 2014. First report of bacterial panicle blight of rice caused by Burkholderia glumae in South Africa. Plant Disease 98(4): 566. 